\title{
THE EFFECT OF THE BLENDED LEARNING MODEL ON THE IMPROVEMENT OF STUDENT LEARNING OUTCOMES
}

\author{
Badrus $^{1}$, Zaenal Arifin ${ }^{2}$ \\ The Islamic Institute of Tribakti Lirboyo Kediri, Indonesia ${ }^{1,2}$ \\ Badrus.kdr@gmail.com, zae.may13@gmail.com
}

Accepted: 24-02-2021

\begin{abstract}
The purpose of the study was to analyze the effect of the blended learning model towards learning outcomes of the comprehension concepts and economic problems solving of Private Islamic High School students in Nganjuk Regency. The study used an experimental method, with a quasi-nonequivalent control group design. The research was conducted at Private Islamic High School Al Manar Prambon Nganjuk. The samples were conducted based on students' characteristics and similarities in economic topics. The experimental class was assigned to XI Social 1 and the control class was XI Social 2. The analysis technique used was descriptive statistical technique and two-ways MANAVA. Descriptive statistics were seen from the mean, standard deviation, variance, and presentation. The results of the MANAVA test analysis when viewed from the centroid pillar's trace, Wilks' lambda, hotelling's trace, and Roy's lambda root in the experimental class had a significance value of 0.000 . The value was transformed to the Fisher distribution or F test, then it is smaller than $\alpha<0.050$. The study shows that the blended learning model has an effect on the learning outcomes of comprehension concepts and economic problems solving of Private Islamic High School students.
\end{abstract}

Keywords: Blended learning, Conceptual understanding, Problem-solving, Economics

\begin{abstract}
Abstrak
Tujuan penelitian ini untuk. menganalisis pengarub model pembelajaran blended learning terhadap hasil belajar pemahaman konsep dan pemecahan masalah ekonomi siswa Madrasah Aliyah Suasta di Kabupaten Nganjuk. Penelitian ini menggunakan metode eksperimen, dengan desain quasi nonequivalent control group. Penelitian ini dilaksanakan di Madrasah Aliyah Al Manar Prambon Nganjuk. Pengambilan sampel dilakukan berdasarkan karakteristik siswa dan kesamaan topik ekonomi. Kelas eksperimen ditentukan di kelas XI IPS1 dan kelas kontrol di kelas XI IPS2. Teknis analisis yang digunakan yaitu teknis statistik. deskriptif dan MANAVA dua arah. Statistik deskriptif dilibat dari rerata, standar deviasi, varian dan persentasi. Hasil analisis uji MANAVA apabila ditinjan dari centroid Pillar's trace, wilks' lambda, hotelling's trace dan roy's lambda root, di kelas eksperimen memiliki nilai signifikansi 0.000. nilai ini ditransformasikan ke distribusi Fisher atau uji F, maka lebih kecil $a<0,050$. Penelitian ini menunjukean bahwa model pembelajaran blended learning berpengarub terhadap hasil belajar pemahaman konsep dan pemecahan masalah ekonomi siswa Madrasah Aliyah
\end{abstract}

Kata Kunci: Blended learning, Pemahaman konsep, Pemecahan masalah, Materi Ekonomi 


\section{INTRODUCTION}

The study of learning strategies to improve learning outcomes in understanding concept and economic problem solving students need to be continuously improved. It is important to remember one of the indicators of the success of the output of secondary school including Private Islamic High School is the realization of graduates who are self-sufficient in terms of the economy. Therefore, it is very urgent to build understanding of concepts as well as solving the economic problems of the students as they learn on the school. Another important thing to be noted is the presence of a number of graduates of the Private Islamic High School predicted still a lot of unemployed because it has not been able to solve economic problems.

The unemployment rate is so high it needs to get solutions from various authorities that is caused by various factors. Namely, the there are low economic growth, inflation, poverty, and the factors of low wages. ${ }^{1}$ The results of the same study stated that inflation, economic growth, and the unemployment rate previously jointly affect unemployment. ${ }^{2}$ Statement of the results of research astonishing is that the factor that is large enough to affect unemployment is of the weak human resources graduate high school. It is characterized by a large number of unemployed high school graduates and Islamic High School. ${ }^{3}$

The two studies above have found the reason for the occurrence of unemployment. But these reasons only show the external reasons and not give a solution to solve the problem of unemployment. This study focuses on understanding the concepts and solving the economic problems of the students of Private Islamic High School.

The focus of research is important to remember the facts of what happened contradictory with the reality of the learning economy studied in Private Islamic High School. Ideally, the knowledge economy has been dominated by graduates of the Private Islamic High School, because of the economic lessons they already studied for three years, starting from class X to class XII, and there are additional subjects of entrepreneurship in each department with a period of study of three years.

From the problems of low economic knowledge graduates of the Private Islamic High School above caused by the learning economy not reached the target. So, though they learned them for a long time even up to three years, the results of their study are not able to solve unemployment, even the unemployed themselves.

One of the efforts to improve the capability of understanding and solving economic problems is educating them with a blended learning model. This Model of learning is believed to improve the ability of students is wide including master economic concepts. The results of the research Sudarman, 2014 stating that the use of the learning model of blended learning significantly better than the strategy of learning face to face in providing the acquisition of learned concepts and procedures of statistics. ${ }^{4}$ According to (Oxford dictionary, 2020)

${ }^{1}$ Rosalendro Eddy Nugroho, "Analisis Faktor - Faktor yang Mempengaruhi Pengangguran di Indonesia Periode 1998 - 2014," Jurnal PASTI (Penelitian dan Aplikasi Sistem dan Teknik Industri) 10, no. 2 (July 21, 2017): 177-91.

2 I. Imsar, "Analisis Faktor-Faktor Yang Mempengaruhi Tingkat Pengangguran Terbuka Di Indonesia Periode 1989-2016," HUMAN FALAH: Jurnal Ekonomi Dan Bisnis Islam 0, no. 0 (June 30, 2018), http://jurnal.uinsu.ac.id/index.php/humanfalah/article/view/1692.

3 Dharfan Aprianto and Ulfah Khairrunnisa, "Hubungan Sumber Daya Manusia Terhadap Tingkat Pendidikan Dan Pengangguran Terbuka Di Indonesia," Prosiding PESAT 5, no. 0 (2013), https://ejournal.gunadarma.ac.id/index.php/pesat/article/view/1230.

${ }^{4}$ Sudarman Sudarman, "Pengaruh Strategi Pembelajaran Blended Learning Terhadap Perolehan Belajar Konsep Dan Prosedur Pada Mahasiswa Yang Memiliki Self-Regulated Learning Berbeda," Jurnal Pendidikan Dan Pembelajaran (JPP) 21, no. 1 (April 14, 2015): 107-17. 
Blended learning is style of education in which students learn via electronic and online media as well as traditional face-to-face teaching. The conclusion is that the blended learning model is a learning environment designed to unite the learning face to face with online learning, which aims to improve the learning outcomes of students.

In addition, it can improve the results of learning. A blended learning model can increase the attractiveness of the process of learning face-to-face and is very suitable to be applied in the era of 21. This is because blended learning can accommodate the development of a broad technology, without having to leave the learning face-to-face. Blended learning can also help teachers to prepare students with different learning styles and help students to face challenges in the future. ${ }^{5}$ the Challenges future is major economic problems. Because it's an economic problem need to get special attention from all authorities.

This study was conducted in Private Islamic High School in Nganjuk Regency. The consideration is Private Islamic High School in the Nganjuk district quite a lot, not less than 32 institutions spread throughout the region Nganjuk. According to the conditions of the society, in general, the students of Private Islamic High School come from a lower middle family. Nganjuk regency is known as the area that classified as a lower-middle-income economy. The number of poor people two years ago is still relatively high at 13. 650.000 Soul or $13,14 \%$ of the total population. ${ }^{6}$ This research is expected to have contributed to accelerate the economic growth in this region.

This study is present to analyze the influence of the learning model of blended learning on the understanding of concepts and problem solving with the establishment of the economic students of The Private Islamic High School in Nganjuk Regency. Then, it needs tracking the factors that influence the effectiveness of the development of the blended learning model in understanding concepts and solving problems.

\section{METHOD}

Methods this study used an experimental method. While the design of this research using quasi-nonequivalent control group. The research population is all students in Private Islamic High School Al Manar Prambon Nganjuk. Sampling was done based on the characteristics of the students and the similarity of economic topics. The experimental class is defined in class XI IPS1 and the control class in XI IPS2.

Data collection techniques is using tests with the goal of getting the value of understanding concepts and solving economic problems. Measurement techniques used on the posttest to get the value of understanding concepts and solving economic problems. The form of the test used to obtain the value of understanding the concept of economy of 20 questions, while the test for problem-solving used 10 questions.

Treatment learning blended learning for 12 times is by face-to-face. The details, all faceto-face pretest and once face-to-face last posttest. The analysis technique used is the technique of data analysis quantitative, namely the techniques of descriptive statistics and MANAVA two directions. Descriptive statistics is seen from the average, standard deviation, variants, and presentation

The results of the assessment in determining the scale score used the guidelines of the Poerwanto. With the table as follows below:

${ }^{5}$ Deklara Nanindya Wardani, Anselmus JE Toenlioe, and Agus Wedi, "Daya Tarik Pembelajaran Di Era Abad 21 Dengan Blended Learning," Jurnal Kajian Teknologi Pendidikan 1, no. 1 (May 23, 2018): 13-18.

${ }^{6}$ Ida Nuraini, "Kualitas Pertumbuhan Ekonomi Daerah Kabupaten/Kota Di Jawa Timur," in Seminar Nasional \& Call For Paper, FEB Unikama (Peningkatan Ketahanan Ekonomi Nasional Dalam Rangka Menghadapi Persaingan Global, Malang: semnas.unikama.ac.id, n.d.). 
Tabel 01: Category Percentage The Value Of The Point ${ }^{7}$

\begin{tabular}{|c|c|c|c|}
\hline The Level & of & Value $\quad$ Of & Predicate \\
\hline Adherence & & The Letters & \\
\hline $89-100 \%$ & & A & Very Good \\
\hline $76-85 \%$ & & B & Good \\
\hline $60-65 \%$ & & $\mathrm{C}$ & Enough \\
\hline $55-59 \%$ & & $\mathrm{D}$ & Less \\
\hline$\leq 54 \%$ & & $\mathrm{E}$ & Very Less \\
\hline
\end{tabular}

(Source: Ngalim Purwanto. Ilmu pendidikan teoritis dan praktis. Bandung : Remaja Karya, 2002)

\section{RESULTS AND DISCUSSION}

The results of the analysis testing the understanding of economic concepts by learning blended learning model descriptively can be described in the following table:

Table 02: The Description of the Data Posttest Understanding of the Concept and Problem-solving Economic Issue

\begin{tabular}{|c|c|c|c|c|}
\hline \multirow[t]{2}{*}{ Value } & \multicolumn{2}{|c|}{$\begin{array}{c}\text { Capability of Understanding } \\
\text { The Concept }\end{array}$} & \multicolumn{2}{|c|}{ Problem Solving Ability } \\
\hline & $\begin{array}{c}\text { Experimental } \\
\text { Class }\end{array}$ & $\begin{array}{l}\text { Control } \\
\text { Class }\end{array}$ & $\begin{array}{c}\text { Experimental } \\
\text { Class }\end{array}$ & $\begin{array}{c}\text { Control } \\
\text { Class }\end{array}$ \\
\hline Sample & 32 & 32 & 32 & 32 \\
\hline Average & 71.28 & 65.37 & 76.34 & 60.03 \\
\hline Standard Deviation & 6.228 & 6.738 & 6.813 & 6.07 \\
\hline Variant & 38.789 & 45.40 & 46.43 & 36.87 \\
\hline Percentage & $52 \%$ & $48 \%$ & $56 \%$ & $44 \%$ \\
\hline
\end{tabular}

The above table explains that the value of the posttest understanding of the concept of the average student gets the value of "Enough" and problem-solving ability gets the value of the "Good" after learning with a blended learning model. While in the control class average achievement of the ability to understand the concept gets the value of "enough" similarly problem-solving ability also gets the value of "Enough" after learned with the conventional model of the economic material in class XI IPS Private Islamic High School Al Manar Prambon Nganjuk.

In the form of the chart, it looks in there that achievements learn some ways the students to understand the concept of the economy between the students who learned with blended learning with the conventional model.

${ }^{7}$ Ngalim Purwanto, Ilmu Pendidikan Teoritis Dan Praktis (Bandung: Remaja Rosdakarya, 2002). 
Figure. 1. Comparison experimental Class dan Control Class

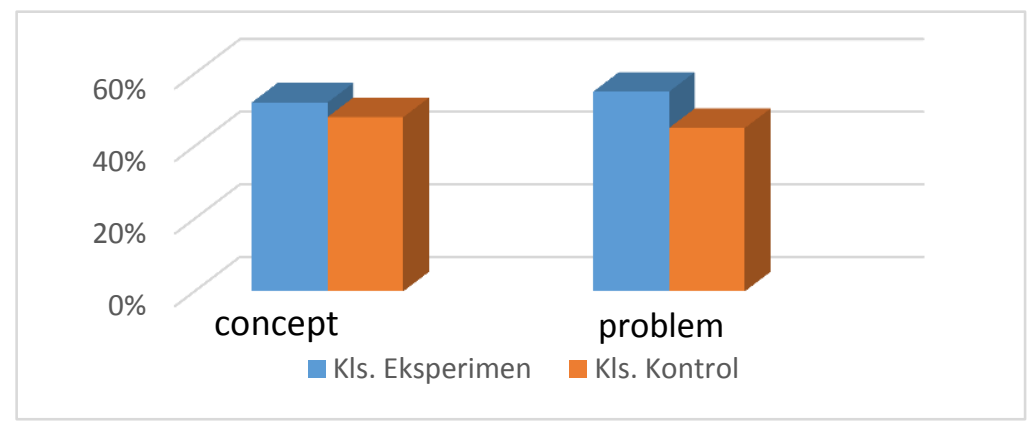

The table above shows that the value of conceptual understanding in the experimental class is higher than in the control class. Thus, the value of problem-solving ability is higher in the experimental class than in the control class.

The effect of the blended learning model on concept understanding and problem-solving using two-way MANAVA analysis on students of Private Islamic High School Al Manar Prambon. The results of the analysis are as follows:

Table 03: Results of the MANAVA Significance Test

\begin{tabular}{ccc}
\hline Effect & & Significance \\
\hline Experimental class & Pillai's Trace & 0.000 \\
& Wilks' Lambda & 0.000 \\
& Hotelling's Trace & 0.000 \\
Control Class & Roy's Largest Root & 0.000 \\
& Pillai's Trace & 0.000 \\
& Wilks' Lambda & 0.000 \\
& Hotelling's Trace & 0.000 \\
& Roy's Largest Root & 0.000 \\
\hline
\end{tabular}

From the results of the MANAVA test analysis above, when viewed from the centroid pillar's trace, Wilks' lambda, hotelling's trace, and Roy's lambda root, between the experimental class and the control class both have a significance value of 0.000 . This value when transformed into the Fisher distribution or the F test, then all of them are smaller $\alpha<0.050$. It can be concluded that both the blended learning model and the conventional learning model can influence the ability to understand concepts and solve problems. However, the difference is in the average value achievement. For the ability to understand concepts in the experimental class the average value is 71.28 while the control class is 65.37 . Likewise, the average ability to solve economic problems in the experimental class is 76.34 while the control class is 60.03 .

There are several factors that influence the achievement of higher concept understanding for students who are taught using the blended learning model, including:

\section{Students explore freely the understanding from the internet}

When students have difficulty get the understanding of economic concepts in the classroom, whether in the classroom in person or in a virtual classroom, they have the opportunity to seek new understandings online. Students read freely a number of economic 
understandings from various sources available on the internet, both from Wikipedia, journals, books, and freelance writings that are published on the internet.

\section{Students are motivated to learn more}

Using blended learning, students are motivated to expand their way of learning through exploration on the internet. They will try to improve their understanding of the subject matter received. Using a good understanding, students will certainly get good learning results. The results showed that the concept and fluency of economic material were influenced by the learning strategies used. The results of the MANOVA analysis is used by the researchers showed that learning with the blended learning model had a better effect on understanding the economic concept of class XI MA Al Manar Prambon and MA Al Khidmah Ngronggot compared to conventional models. This can happened because the learning procedure of blended learning goes through two stages. The first stage is face to face, students and teachers meet face to face. In the second stage, students are directed to the computer laboratory room. In the first stage, students explained the meaning of economy, economic growth, and a glimpse of the factors that affect economic growth. In the second stage, students are directed to a computer laboratory. In this lab, students are assigned to surf and find out more about the factors that affect economic growth. Why the stock of capital goods can affect economic growth. Why land area affects economic growth. Why the application of technology can also affect economic growth. To answer this problem, students use a lot of learning resources such as books, newspapers, and a number of online sources that are widely available on the internet, students are easy to find the true meaning of the material being discussed by drawing conclusions from the learning resources obtained. Thus students can understand the concepts discussed properly.

Another thing that can motivate students to learn online is discussion. The discussion in question is an online conversation between students and students and between students and teachers. In this discussion, students have the opportunity to express opinions, express their understanding regarding the material being discussed, and ask questions or problems that have not been understood. In addition, students are also given the opportunity to answer questions from friends or from their teachers. In this discussion session when they experience a mistake in understanding a concept, other students or teachers can immediately improve students' understanding by providing correct explanations or understandings. Discussions in online learning can be carried out by students whenever and wherever they use their respective computers or cellphones. This online learning provides unlimited opportunities for students to learn. They can access the Edmodo discussion forum or Google classroom whenever and wherever they want, as long as they have an internet connection. Learning like this certainly will not make students feel bored or tired in studying, because they can learn when they feel there is an opportunity and want to learn.

In online discussions, the teacher invites students to solve problems with the correct procedure. Problems that have not been resolved, students can ask other friends to help them. Thus in blended learning is teaching children to collaborate and collaborate during learning. This certainly contributes positively to the continuity of learning, where students who have high academic abilities are expected to be able to guide other students who have moderate or low academic abilities.

\section{Students have the convenience and acceleration of learning}

Blended learning provides convenience and acceleration according to the abilities of each student. Students learning through the internet can reach more material in a shorter time according to their respective learning styles. And more importantly, online learning is often pursued by self-study, which is more fun and takes the stress out of the equation. 


\section{Build student involvement in learning}

Blended learning in building student involvement in learning is quite high. So far, the biggest challenge in the learning process is building student involvement in learning. It should be understood that the attention span of students is very short, while the target to be achieved is quite large. On average, students began to decrease their level of attention between 8 to 10 minutes in face-to-face with the speaker. ${ }^{8}$ Therefore, blended learning is a model that can provide opportunities for students, with pleasure, they use the internet to learn.

\section{Provide an element of novelty in the internet}

The analysis result shows that the value of solving economic problems in the experimental class is higher than in the control class. This is caused by the novelty in data on the internet that has been discovered by students. With the new elements that are obtained, students will tend to continue their learning until they reach a climax when they are successful.

\section{Learning Outcomes of Economic Problem Solving Ability}

Based on the Manova analysis, it was found that the $\mathrm{F}$ value in the problem-solving column was 77.561 with a significance of 0.000 . This significant value is smaller than the significance level of 0.05 . This statistical value means that there is a difference in the average score of learning outcomes in solving economic problems between groups of students who learn using the blended learning model and groups of students who learn using conventional models. The learning outcomes of economic problem solving achieved by students who take blended learning models are better than students who take conventional learning models.

\section{Strong mental action}

In practical terms, it can be explained that blended learning in the problem-solving stage through student activity sheets in Google classroom can bring out stronger mental action of students. One indicator of the stronger mental strength of children is that 70 percent of the respondents participate in discussions. Starting from asking questions, expressing opinions, and raising objections to the information from the presenter. However, not all students are successful in solving problems. If there is a student's expected mental action that does not appear or students experience collapse in solving the problem at hand, the teacher intervenes by providing guidance or relevant examples. Give the opposite example, through questions that lead students to find solutions. Teacher treatment like this according to Weeks, is an effective way of enhancing learning. ${ }^{\text {' }}$

\section{Increased understanding of problems in the real life}

At the discussion or sharing stage on Google classroom, the students seemed noisy, conveying messages to each other. Discussion is a vehicle for exchanging opinions, where it requires students to be responsible with others in a social context. In addition, in the discussion, the involvement of peer students is more visible, and the more intensive the involvement of fellow students can improve learning outcomes. Engagement with fellow students opens opportunities for students to evaluate and improve their understanding when they encounter the thoughts of others and when they participate in a search for common understanding. ${ }^{10}$

${ }^{8}$ Neil A. Bradbury, "Attention Span during Lectures: 8 Seconds, 10 Minutes, or More?," Advances in Physiology Education 40, no. 4 (November 8, 2016): 509-13, https://doi.org/10.1152/advan.00109.2016.

${ }_{9}$ F. H. Weeks, "Behaviour Problems in the Classroom : A Model for Teachers to Assist Learners with Unmet Emotional Needs," 2000.

${ }^{10}$ Ra'ed Abdelkarim and Reem Abuiyada, "The Effect of Peer Teaching on Mathematics Academic Achievement of the Undergraduate Students in Oman," International Education Studies 9, no. 5 (April 26, 2016): p124, https://doi.org/10.5539/ies.v9n5p124. 


\section{Increased self-awareness}

The final stage of problem-solving is evaluation. This stage has characteristics, one of which is guiding students to constantly re-check all their performance. In this stage, it is expected that mental actions will appear that make students not immediately satisfied with the results of their performance, before evaluating or re-examining their performance results. On the other hand, through the evaluation stage, students will get to know themselves better. This means that students are aware of their own level of ability and can increase their motivation, such as knowing the extent to which they have mastered the information provided to solve the problems at hand.

\section{Experiencing potential developments}

Exploration activities carried out by students in constructing their knowledge through teaching materials designed to challenge students are learning based on constructivism. In addition, knowledge construction and multi-directional interactions that occur in the Google classroom will cause the development of maximum cognitive abilities in students, including actual and potential development. Students who try to solve problems independently without expecting any intervention through outside interaction, said Vygotsky can help them solve problems, are said to experience potential development. According to Vygotsky, the distance between these two developments is called the zone of proximal development. ${ }^{11}$ So, a person in his studies will experience potential developments that are influenced by the environment he is in. This condition is in accordance with the principles of social constructivism.

Thus, studying economics with the blended learning model can be said to have a relationship with social constructivism to develop cognitive abilities, both actual development and potential development in students.

The ability to understand and solve economic problems is part of the power of social abilities, which need to be developed in children in learning economics. Among other abilities such as; Organizing, finding meaning and applying are important for students to have. Therefore, it is very natural that the ability to understand concepts and solve economic problems is a concern of economics teachers, especially at the high school level, as an effort to improve learning outcomes and the quality of economic education in Indonesia. In addition, teachers must be able to develop a positive attitude towards the economy. Because the existence of a positive attitude towards the economy will have an impact on increasing economic learning outcomes.

Furthermore, in the problem-solving stage through student activity sheets it is expected that students' mental actions will emerge. However, if the expected mental action of students does not appear or students experience a collapse in solving the problem at hand, the teacher intervenes by providing relevant guidance or examples, giving the opposite example, through questions that lead students to find solutions. Teacher treatment like this is an effective way to improve learning. ${ }^{12}$

The discussion or sharing stage also requires students to be responsible with others in a social context. In addition, in the discussion, the involvement of peer students is more visible, and the more intensive the involvement of fellow students can improve learning outcomes. Engagement with fellow students opens opportunities for students to evaluate and refine their understanding when they encounter the thoughts of others and when they participate in a search for common understanding. ${ }^{13}$

${ }^{11}$ Lev Semenovič Vygotskij and Michael Cole, Mind in Society: The Development of Higher Psychological Processes, Nachdr. (Cambridge, Mass.: Harvard Univ. Press, 1981).

12 Dale H. Schunk, Learning Theories: An Educational Perspective, 6th ed (Boston: Pearson, 2012).

${ }^{13}$ John W. Santrock, Educational Psychology, 4th ed (Boston: McGraw-Hill, 2009). 


\section{CONCLUSION}

Finally, this study can be concluded that from the results of the MANAVA test analysis, when viewed from the centroid pillar's trace, Wilks' lambda, hotelling's trace, and Roy's lambda root, the experimental class has a significance value of 0.000 . This value when transformed to the Fisher distribution or F test, then it is smaller than $\alpha<0.050$. This study shows that the blended learning model has an effect on the learning outcomes of understanding the concept and solving economic problems of students of Private Islamic High School.

\section{REFERENCES}

Abdelkarim, Ra'ed, and Reem Abuiyada. "The Effect of Peer Teaching on Mathematics Academic Achievement of the Undergraduate Students in Oman." International Education Studies 9, no. 5 (April 26, 2016): p124. https://doi.org/10.5539/ies.v9n5p124.

Aprianto, Dharfan, and Ulfah Khairrunnisa. "Hubungan Sumber Daya Manusia Terhadap Tingkat Pendidikan Dan Pengangguran Terbuka Di Indonesia." Prosiding PESAT 5, no. 0 (2013). https:/ / ejournal.gunadarma.ac.id/index.php/pesat/article/view/1230.

Bradbury, Neil A. "Attention Span during Lectures: 8 Seconds, 10 Minutes, or More?" Advances in Physiology Education 40, no. 4 (November 8, 2016): 509-13. https://doi.org/10.1152/advan.00109.2016.

Imsar, I. "Analisis Faktor-Faktor Yang Mempengaruhi Tingkat Pengangguran Terbuka Di Indonesia Periode 1989-2016." HUMAN FALAH: Jurnal Ekonomi Dan Bisnis Islam 0, no. 0 (June 30, 2018). http://jurnal.uinsu.ac.id/index.php/humanfalah/article/view/1692.

Nugroho, Rosalendro Eddy. "Analisis Faktor - Faktor yang Mempengaruhi Pengangguran di Indonesia Periode 1998 - 2014." Jurnal PASTI (Penelitian dan Aplikasi Sistem dan Teknik Industri) 10, no. 2 (July 21, 2017): 177-91.

Nuraini, Ida. "Kualitas Pertumbuhan Ekonomi Daerah Kabupaten/Kota Di Jawa Timur." In Seminar Nasional \& Call For Paper, FEB Unikama. Malang: semnas.unikama.ac.id, n.d.

Purwanto, Ngalim. Ilmu Pendidikan Teoritis Dan Praktis. Bandung: Remaja Rosdakarya, 2002.

Santrock, John W. Educational Psychology. 4th ed. oston: McGraw-Hill, 2009.

Schunk, Dale H. Learning Theories: An Educational Perspective. 6th ed. Boston: Pearson, 2012.

Sudarman, Sudarman. "Pengaruh Strategi Pembelajaran Blended Learning Terhadap Perolehan Belajar Konsep Dan Prosedur Pada Mahasiswa Yang Memiliki SelfRegulated Learning Berbeda." Jurnal Pendidikan Dan Pembelajaran (JPP) 21, no. 1 (April 14, 2015): 107-17.

Vygotskij, Lev Semenovič, and Michael Cole. Mind in Society: The Development of Higher Psychological Processes. Nachdr. Cambridge, Mass.: Harvard Univ. Press, 1981.

Wardani, Deklara Nanindya, Anselmus JE Toenlioe, and Agus Wedi. "Daya Tarik Pembelajaran Di Era Abad 21 Dengan Blended Learning." Jurnal Kajian Teknologi Pendidikan 1, no. 1 (May 23, 2018): 13-18.

Weeks, F. H. "Behaviour Problems in the Classroom : A Model for Teachers to Assist Learners with Unmet Emotional Needs," 2000. 